\title{
The Importance of being Erroneous
}

\author{
Nils Kürbis \\ Published in Australasian Philosophical Review 3/2 (2019): 155-166 \\ http://dx.doi.org/10.1080/24740500.2020.1716661
}

\begin{abstract}
In this commentary, I draw parallels between the sophists' and the Socratic account of meaning that McCabe reconstructs from the Euthydemus and views on logic and language found in the works of classical authors of analytic philosophy. I argue that the ingredients of the sophist's account of truth, which McCabe describes as 'chopped logos', correspond to widely held philosophical theses concerning meaning. It shares three of its four ingredients with the direct reference theory of the meanings of proper names. The sophists need a notion of meaning applicable to sayings, not names: they require a notion of truth. This is provided by the remaining ingredient, which is a version of the principle that meanings are truth conditions. The Euthydemus demonstrates dramatically that the combination of the four ingredients is unpalatable. Building on McCabe's point that chopped logos does not get the conditions of failure of sayings right, I conclude that, as the sophists have no notion of falsity of sayings, they have neither a notion of truth nor of meaning.
\end{abstract}

The sophists have striking ideas about meaning. Or maybe it is better to say that they force striking ideas upon Ctesippus. According to the sophists, McCabe explains, 'sayings have content, describing what the sayings are of; and what they are of is their thing, their pragma. This thing they are of fully determines the content of the statement ... the logos I say will correspond exactly to what it is of, whatever that is; and what it is of is what makes it true.' (6f) ${ }^{1} \mathrm{I}$ will call this the sophistic theory of meaning, rather than the sophists' theory of meaning: 'the sophists eschew theory' (3). The Euthydemus demonstrates the absurd consequences of this theory. McCabe's article shows how difficult it is to refute, and not because of the sophists' attitude. What the sophists say is worth taking seriously - even if they themselves are not - and demands a philosophical response. In the following, I will further underpin this claim by drawing parallels between the sophistic theory and contemporary theories of meaning. The sophistic theory respects plausible and commonly accepted views about meaning. It is not just a curiosity some of Plato's contemporaries may have been puzzled about. Plato still has something to show us. ${ }^{2}$

Recall the four ingredients of chopped logos (7f):

\footnotetext{
${ }^{1}$ Numbers in brackets refer to pages of 'First Chop your Logos ...'.

${ }^{2}$ I would like to thank Fiona Leigh for the invitation to comment, and MM McCabe for her paper and for many enlightening philosophical discussions.
} 
1. The relation between a chopped logos and its pragma is 'exclusive, exhaustive and determinate.'

2. Chopped logoi are units that 'resist disaggregation; the correspondence is one-to-one as a whole, or not at all'.

3. The relation between a chopped logos and its pragma 'explicates both truth and meaning at once. What the logos means, it says; and what it says, is so.'

4. There are neither truth-functional nor higher order relations between chopped logoi.

A theory of meaning requires clarity about the categories of expressions. Chopped logoi are, on the face of it, sentences, because the sophistic theory constitutes an attempt to characterise the content of sayings, and sentences say things: sentences are the category of expressions to which the concept of truth applies.

A closer look at McCabe's four ingredients of chopped logos, however, reveals that the second and fourth ingredients are common to chopped logoi and proper names.

The second ingredient means that chopped logoi are not compositional and have no semantically significant structure. The same is true for proper names like 'Theodorus' and 'Dionysodorus'. Some proper names are composed from other expressions, but their composition is not semantically significant. Even though the words making up the name 'The Eleatic Stranger' are not picked at random, but because the person named is a stranger from Elea, nonetheless, 'The Eleatic Stranger' names the stranger from Elea, not because he is the stranger from Elea, but because Theodorus introduces him by saying he brought with him 'a stranger from Elea' (Sophist 216a2-3, tr. Fowler) ${ }^{3}$ and thereby gives him that name. His act of naming would not have gone wrong had there been another stranger from Elea in the Lyceum. Contrast with 'the way to Larissa': even if there was only one way to Larissa, what is being talked about by that expression depends on where Larissa is and how to get there, by what is meant by 'Larissa' and 'being a way to'. Proper names do not get their meanings from their composition, as they may not be composed. The syntactic structure a proper name may exhibit is not semantically relevant.

The fourth ingredient is that there are no truth-functional or higher order relations between chopped logoi. (8) Neither are there between between names. 'If Euthydemus, then Dionysodorus' is meaningless, and so are 'Euthydemus and Dionysodorus' and 'Euthydemus or Dionysodorus', if 'and' and 'or' are truth functions. Applying a name to another, as in 'Euthydemus Dionysodorus', does not produce a meaningful expression either. Complex grammatical subjects such as 'Euthydemus and Dionysodorus' and 'Euthydemus or Dionysodurus' are not names. There is no one thing named by 'Euthydemus or Dionysodorus' in 'Who is speaking, Euthydemus or Dionysodorus?', nor by 'Euthydemus and Dionysodorus' in 'Euthydemus and Dionysodorus are arguing'.

In as much as chopped logoi share features with proper names, the first ingredient of chopped logos places the sophistic theory of meaning for sayings in the vicinity of a specific theory of meaning for proper names: the direct reference theory. This theory is generally traced back to Mill. Proper names 'are

\footnotetext{
${ }^{3} \mathrm{He}$ is not quite so neatly introduced in White's translation, where Theodorus presents him as 'this man who is visiting us'.
} 
simply marks used to enable [...] individuals to be made subjects of discourse.' (Mill, J.S., 1882, book 1, chapter 2, §5) Proper names contribute only their bearers to the meanings of sentences in which they occur. The meaning of a proper name is exhausted by its bearer. Proper names are mere tags of objects, in Barcan Marcus's terminology. (Barcan Marcus, 1961, 310) A tag tags exactly one thing, which is just as McCabe describes the first ingredient of chopped logos: 'the relation between a logos and what is of is exact: exclusive, exhaustive and determinate' (7). Chopped logoi are tags of their pragma.

If a tag is attached to more than one thing, then those things are treated as a unity for the purpose of tagging. When Theodorus hands the stranger from Elea the name tag 'The stranger from Elea', the tag does not tag the limbs, head, torso and soul, if you wish, of the stranger from Elea, but them as a whole, even if the person was merely the aggregate of its physical and mental constituents. 'Athens' does not tag the Acropolis, the Agora etc. the but the city of Athens, even if there is no more to that city than its parts.

Something that is not tagged to anything is not a tag in the sense intended by the direct reference theory. The analogy between naming and tagging invites a comparison of proper names to tags for luggage, folders, parcels, etc. or name tags for people. Such tags may not (yet) tag anything and may never do so. The direct reference theory can exclude them, they are not (yet) serving their purpose.

Although the sophists would resit any further exploration of the theory, a serious direct reference theorist may want to say few more words about names such as 'Pegasus' or, indeed, the names of characters in Plato's dialogues, who, McCabe argues, are characters of fiction, despite their affinities to real persons. (McCabe, MM, 2000) ${ }^{4}$ But whatever a direct reference theorist may say about names of fiction, if the meaning of a proper name is exhausted by the object it names, and there is nothing to be named, something has gone wrong.

Two syntactically identical expressions can name more than one person, as, for instance, 'Socrates' names the old Socrates and the young Socrates of the Statesman. For the direct reference theory, however, these are semantically two different names. They contribute different objects to the meaning of an utterance such as the Eleatic Stranger's 'Socrates, do you hear what Socrates says?' (Statesman 258a7, tr. Rowe) Old Socrates could instead be called 'Osocrates' and young Socrates ' $Y$ socrates'.

Two syntactically different expressions, can be proper names of the same object, but for the direct reference theory, semantically they are the same proper name. If 'The Morning Star' is a tag for the same object as 'The Evening Star', then they mean the same thing. If they mean different things, they cannot both be proper names of the planet Venus, but must name something else, maybe its appearances at different times of the day.

The view that the meanings of proper names are exhausted by their bearers is not unattractive. It is an educated guess that most philosophers of language agree that Mill was fundamentally right about the semantics of proper names. Were the sophists to restrict their claims to ingredients one, two and four of

\footnotetext{
${ }^{4}$ Plato says next to nothing about who Euthydemus and Dionysodorus are. Are they such surreal characters that no real person could suffer any affinity with them? Are they worse than Heraclitus and Protagoras, agreeing, as they appear to do, that their father is a dog and a boar, their siblings sea urchins, gudgeons, puppies and piglets? (Euthydemus 298c8-d6, following Kent Sprague's translation.)
} 
chopped logos, they would merely put forward the most commonly held theory of meaning for that specific category of expressions.

The crux lies in the third ingredient, which introduces the notion of truth: the truth and meaning of a chopped logos are inseparable. It is this aspect of the sophistic theory of meaning that makes it one about sayings.

The third ingredient of chopped logos is a sophistic version of the common view that meaning and truth are closely related: the meanings of sentences are their truth conditions. McCabe argues that it is common ground to Socrates and the sophists that to say, legein, is an action (prattein), and that logoi are somehow related to (some corresponding) pragmata. [...] For the activity of legein, the sophists declare - and Socrates and his friends seem to agree - that the relation between the sayings and the things is the truth-telling relation.' (19f) Many philosophers agree, too, amongst whom Frege: the meaning, or sense, in his terminology, of a sentence, the thought it expresses, is that the conditions for its truth are fulfilled. (Frege, 1893, §32) The sophists twist this reasonable view into the denial of the claim that the truth-telling relation may fail to hold between meaningful items and the things by combining it with the other three ingredients of chopped logos.

The view that emerges is that the sophistic theory of meaning treats sentences as proper names, where the semantics of proper names is given by the direct reference theory. It is a direct reference theory of logoi. The result is an equation of truth conditions with truth. The sophists' desired conclusions follow. If I name a thing one way, and you name the same thing another way, then there is a chance we'll end up taking past each other, but we are not contradicting each other. If I give a thing a name and you don't, then, although we may not share the same interests, this gives us no grounds for argument. An attempt at naming can go wrong, if there is nothing to be named, but then no naming has happened. As McCabe puts it, 'if and only if I say, what I say is about the pragma and true.' (20) A saying is true if and only if it is meaningful. You either speak truly or you don't speak at all. Falsehood and countersaying are impossible. Realising what has struck him, Ctesippus falls silent.

If chopped logoi are proper names, the question arises, what are they proper names of? As chopped logoi are true, the obvious suggestion is that they are proper names of facts or truth makers.

The view that sentences name facts or truth makers is not unattractive. Replace 'name' by 'refer to'. According to Dummett, Frege used 'the name/bearer relation as the prototype of the relation of an expression to its referent.' (Dummett, 1981, 190) Some may even argue that naming is the paradigm of linguistic use, with everything else falling into place. This is the picture of language Wittgenstein attributed to Augustine and his former self. (Wittgenstein, 1953, $\S 1, \S 46)$ Less dramatically, Dummett, who agrees with Frege that reference is a phenomenon broader than just the relation between a name and its bearer, proposes that reference may be the core notion of a theory of meaning, with truth a special case of reference.

Fleshing out some more what reference is, Dummett writes that 'the realm of reference just is reality, that reality of which we speak and in virtue of which the thoughts which we express are true or false' (Dummett, 1981, 153f) and that 'the referents of our words are what we talk about.' (Dummett, 1981, 196) With this characterisation of reference, extending the notion of reference to parts of speech other than names, it is natural to say that predicates and verbs refer 
to properties or universals, as did Russell. (Russell, 2001, 145) And to what should sentences refer other than facts or truth makers? Russell expressed this view in one of his most famous works. 'Out of any proposition we can make a denoting phrase, which denotes an entity if the proposition is true, but does not denote an entity if the proposition is false.' (Russell, 1905, 490) Russell treats those entities as certain kinds of complex objects. 'If A loves B, there is such a complex object as "A's love for B," and vice versa; thus the existence of this complex object gives the condition for the truth of the judgement "A loves B."' (Russell, 1910, 183) According to Russell's celebrated analysis, 'denoting phrases never have any meaning in themselves, but [...] every proposition in whose verbal expression they occur has a meaning.' (Russell, 1905, 480) In 'the proper analysis', denoting phrases disappear and every sentence in which they occur is assigned a proposition as its meaning that uses as primitives only expressions of predicate logic. Thus the meaning of any sentence in which 'the complex of A's love for B' occurs, such as 'The complex of A's love for B exists', is given by a sentence in which it does not occur, in this case 'A loves B'. Nonetheless, Russell asserts that there is a close link between the existence of certain complexes and the truth conditions or meanings of propositions.

If truth is a special case of reference and sentences names of facts, the sophists get what they want. The problem is not that the sophistic theory of meaning treats sentences as proper names. It reappears if they are part of a broader category comprising also complex names. ${ }^{5}$ Even though in the Euthydemus logoi are treated as unstructured, in the Theaetetus the problem is formulated independently of structure. At 189a6-189b2, Socrates presents the following brief argument: 'A man who is judging some one thing is judging something which is. Then that means that a man who is judging something which is not is judging nothing. But a man who is judging nothing is not judging at all. And so it is not possible to judge what is not, either about the things which are or just by itself.' (Following Levett's translation, turning Socrates' questions into assertions and omitting Theaetetus' interjections.) Never mind the structure of the name. I'm not talking about anyone with 'the present King of France' and the phrase cannot get its meaning from its purported reference to such a person. The meaning of a proposition is its truth condition. According to Russell, the latter is given by the existence of a certain complex object. But there is no difference between a complex object and the existence of a complex object. So the meaning of a proposition is given by a certain complex object. Take away the object, and there is nothing that could do the giving. There is no such thing as the non-existence of a certain complex object. Without that complex object, there is neither truth condition nor meaning. There seems to be no way around the conclusion that either there are no false propositions or they are meaningless. The sophists' traps are laid widely.

The argument in the last paragraph is confirmed by Anscombe, who points out that Russell changed his mind on the nature of propositions (Russell, 1918, 507 ) in reaction to the problem of falsity posed by Plato and which is the target of McCabe's paper. ${ }^{6}$ The sophistic theory's simultaneous explanation of meaning and truth delivers on what is expected from a respectable theory of meaning. There may be different conceptions of truth, but according to Dummett 'under

\footnotetext{
${ }^{5}$ Denyer draws a similar conclusion from the Euthydemus (Denyer, 1991, chapter 2).

${ }^{6}$ See (Anscombe, G. E. M., 1971, first chapters). Anscombe quotes Theaetetus 189a6-189b2 on p.13.
} 
any theory of meaning whatever [...] we can represent the meaning (sense) of a sentence as given by the condition for it to be true, on some appropriate way of construing 'true'." (Dummett, 1978, xii) To establish that meaning cannot be explained independently of truth requires an explication of the role of truth within the theory of meaning: 'the notion of truth has no place in the theory of meaning unless there is such a connection [between meaning and truth]; and it therefore becomes a requirement on the theory of meaning that it make this connection explicit.' (Dummett, 1993b, 20) A theory of meaning is not just a theory of meaning, but one of truth, too. 'The concept of truth is intimately bound up with the concept of meaning; no philosophical elucidation of either concept is to be had which does not at the same time provide an elucidation of the other one.' (Dummett, 1993a, 118)

The sophistic theory of meaning cheerfully accepts the challenge. It elucidates truth by assimilating it to the paradigm case of reference, the relation between a name and its bearer. It makes the connection between meaning and truth explicit by equating meaning with truth. McCabe's presentation of the sophistic theory of meaning suggests that the theory of truth that goes with it is, or at least is consistent with, a version of the correspondence theory: true sentences correspond to the facts they refer to.

This should suffice to establish that the sophistic theory of meaning is not mere sophistry, even if that is the use to which the sophists put it. The Euthydemus demonstrates in dramatic form why the theory can't be right. Its consequences are obviously absurd. None of those present in the Lyceum are, I imagine, siblings to sea urchins. But because the sophistic theory of meaning integrates serious philosophical positions, those reluctant to accept it as a genuine theory of meaning need a serious argument.

McCabe argues that to show where the sophists went wrong, Socrates offers a teleological account of saying that is modelled on his solution to the problem of how learning is possible. Learning is a complex process with an aim: to acquire knowledge or understanding or competence. Success is not guaranteed. Socrates achieves more than merely detecting an ambiguity in the verb 'to learn': 'Socrates may, instead, be distinguishing two different aspects (in the grammatical sense) of learning: imperfective (the endeavour of learning: "I learn") versus perfective (the learning that one has when one has learned: "I have learned", "I am learned").' (14) McCabe underlines that the distinction requires metaphysical support. 'Socrates needs to show that there is such a thing as a process and continuity and development rather than a succession of new and distinct events.' (16) Learning and having learnt are not two different states, but the same state in different stages.

The discussion of the sophistic theory of meaning as a direct reference theory of logos highlights McCabe's point. If Socrates' aim was merely to point out "that the verb "to learn" is used of two quite different mental processes or states ("learning" and "understanding")' (13), then he would have no argument against the sophists. Sentences could still be mere tags. In one sense, 'Clinias learns' tags Clinias' learning, in another it tags Clinias' understanding. An ambiguity in the verb 'to learn' is no more a problem for the sophistic theory of meaning than the dual use of 'Socrates' in the Statesman is for the direct reference theory of proper names.

On Socrates' account, McCabe explains, saying is similar to learning. It is an activity with an aim: truth. Thus saying can miss its target. The comparison 
of saying to learning makes sense of the way sayings normally occur. The purpose of saying things, or of communication, is rarely to transmit isolated pieces of information. More often, sayings are part of a conversation. We are both speakers and hearers. The aim and the aiming are complex. Sayings are subject to criticism: they should have adequate grounds. These grounds are interwoven with other sayings and often inconclusive. You can request to hear the reasons for my saying, point out that I'm wrong or that my grounds are insufficient. 'Saying, on this account, is extended, continuous and responsive to questions, just because what it is directed at is something complex: a body of truth (like a body of knowledge) rather than just a single claim.' (25) Failure comes in more than one variety. I may fail to speak truly, but I may also fail to have adequate grounds for my saying, even though what I say is true. I may fail to provide sufficient reasons for my sayings or fail to make my sayings cohere. As a result, I may change my mind and retract what I said: 'not only do I try to speak the truth; but I reflect on whether I am doing so, and commit myself to the result of that reflection when I speak, or revise what I say.' (26) Sayings also have consequences. Accepting a saying commits us to accepting further sayings and actions to be performed in the light of the acceptance. The sophistic theory of meaning, where sayings are isolated tags, cannot make sense of these complex interactions between speakers.

McCabe's analysis of Socrates' account of logos stresses that sayings are embedded in complex practices of interaction, tied to the grounds we have for making assertions and the consequences following from them, the conditions under which we make and retract assertions. This is something we also find in Dummett's writings on the theory of meaning. Our linguistic practice is governed by principles 'that have to do with the circumstances that warrant an assertion, the basis on which we may recognise a statement as having been established [...:] we need to know when we are entitled to make any given assertion, and when we are required to acknowledge it as true. [...] Clearly, however, our use of the language cannot be exhaustively described in terms of [these principles alone]. If that were all, we should be skilled at making assertions but incapable of responding to the assertions of others. [...] In acquiring language, we learn a variety of principles determining the consequences of possible utterances.' (Dummett, 1993b, 210ff) McCabe's Socratic account adds that there are two facets to each of the two principles. We may successfully give the grounds for our sayings or fail to do so, we may successfully follow up on the consequences of our sayings or fail to do so. The Socratic account also adds the importance of the development of thoughts, attitudes and personality in conversation. ${ }^{7}$

Sayings, then, can go wrong in all kinds of ways: I speak falsely, I do not have adequate grounds for my saying, my saying fails to cohere with other things I said, I fail to make good on my saying. By contrast, there is a sense in which naming cannot go wrong. If I decide to tag an object, this is its name in my usage and anyone else's I may convince to follow. A failure to tag an object is not a special kind of tagging, but no tagging at all. I may think that I have named a winged horse 'Pegasus', while in fact I fail to do so, because there are no mythical animals, but, traumatic as such a case may be, if there is no object to

\footnotetext{
${ }^{7}$ Strangely Dummett has no convincing answer to the problem of falsity. His account of meaning allows for the possibility that all sentences of a language are true. See (Kürbis, 2015).
} 
be named, no naming has happened. If there is no object to name, you haven't named. If you speak falsely, unjustifiedly, incoherently or misleadingly, you have nonetheless spoken.

The conditions of failure and success for naming and saying are different. Saying can fail in ways that naming can not. Thus saying is different from naming. ${ }^{8}$

The last conclusion overstates the case slightly. It might still be possible to think of sentences as names, as long as they do not name facts. Frege held that sentences are names, not necessarily proper ones, of two very special, logical objects, the True and the False. All true sentences name the True, all false sentences the False. This ensures that false sentences refer. For Frege, names refer to objects and predicates, not to properties or universals, but to functions from objects to truth values. Differences in meaning are located in the senses of expressions, not, as for Russell, in their references. (See (Anscombe, G. E. M., 1971, 45)) Notice also that Russell's facts are structured, while Frege's truth values are not. The sophists are quite right to insist that chopped logoi resist disaggregation. ${ }^{9}$

Setting aside the Fregean option, we can conclude that reference, reduced to a kind of naming, and reference failure cannot do the job of truth and falsity. There is more to meaning than naming.

That meaning and truth are tied in Dummett's sense is not uncontroversial. The view presupposes that truth, like meaning, is a substantial notion. It must reject the deflationary theory of truth, attributed to Ramsey: 'there really is no separate problem of truth [...] It is evident that "It is true that Caesar was murdered" means no more than that Caesar was murdered.' (Ramsey, 1978, 157) ${ }^{10}$ Whether severing the ties between truth and meaning is a way to escape the sophists is questionable. Whatever the essence of meaning, the world we talk about should be of some importance, and so the problem of falsity remains pertinent. ${ }^{11}$

Two extreme theories of the relation between meaning and truth are worth mentioning. Tarksi's definition of truth for formalised languages employs sentences of one language to specify the truth conditions of sentences in another, so he defines truth in terms of a primitive notion of sameness of meaning. (Tarski, 1956, 187f) Davidson uses Tarski's T-schema to specify the meanings of sentences of the object language and thus defines meaning in terms of a primitive notion of truth. (Davidson, 2001a, xvi) Dummett is somewhere inbetween. ${ }^{12}$ What everyone on the spectrum from Tarski to Davidson agrees on is that the meaning is compositional. The meanings of sentences are determined by the meanings of the expressions occurring in them and how they are assembled.

\footnotetext{
${ }^{8}$ Prior, who discusses the problem of falsehood in relation to the correspondence theory of truth, also concludes that 'naming is one thing, saying or stating another.' (Prior, 1967, 228)

${ }^{9}$ Compare also Davidson's slingshot argument (Davidson, 2001b).

${ }^{10}$ For discussion of the deflationary theory and problems it faces with the liar paradox, see Marques (2018).

${ }^{11}$ Frege accepted that ' $p$ ' and 'It is true that $p$ ' have the same content, so he may have been sympathetic to some aspects of the redundancy theory. But obviously he did not hold a redundancy theory of the True. According to Frege, nothing is added to a thought by ascribing truth to it, just like, one might observe, according to Kant nothing is added to an object by ascribing existence to it. Frege expresses doubts that truth is a property. It is sui generis: "the content of the word "true" is very peculiar and undefinable'. (Frege, 1918a, 60f)

${ }^{12}$ For another intermediate position, inspired by Dummett, see (Weiss, 2007).
} 
A theme of the Euthydemus is the drawing and ignoring of distinctions. Socrates corrects Crito: he was talking to two strangers, not one. Socrates reminds Clinias that the same word can mean different things. Even Ctesippus draws distinctions: 'my noble Dionysodorus, do not call countersaying annoyance: for countersaying is something different' $(285 \mathrm{~d} 4-6)^{13}$. At 290b3-290d8, Clinias suddenly appears to have read the Republic, ${ }^{14}$ and the dialogue turns from Socrates' narrative to the frame story, his encounter with Crito. The question arises whether it could really have been Clinias who had spoken so eloquently or whether some superior being was present. As the frame story continues, different kinds and ways of conducting conversations are demonstrated. Socrates asks for clarifications to avoid that 'you ask a question with one thing in mind and I understand it with another' (295c4-5, tr. Kent Sprague). The sophists tear distinctions down and demand that Socrates ignore them. But the dialogue shows that they, too, acknowledge distinctions: there are Socrates' 'wrong' responses and the 'right' ones that let them play their game. ${ }^{15}$

A very important distinction gets ignored at (285e9-286a1):

'Are there sayings [logoi] for each of the things there are?'

'Certainly.'

'And is a saying for each thing as the thing is or as it is not?'

'As it is.' ${ }^{16}$

At first Dionysodorus talks about things: the sayings are construed as names. Then he shifts to the way things are: the sayings are construed as predications. Ctesippus underwrites his demise by not paying attention to the shift.

Plato draws the distinction between names and verbs and their different functions in the Sophist (261e4ff). The distinction contributes to the solution of two problems, the problem of the difference between a list of words like 'walks runs sleeps' and 'lion stag horse', which say nothing, and sentences like 'Theaetetus sits' and 'Theaetetus flies', which say something, and the problem of how sentences can be false yet meaningful.

For simplicity I'll classify the verbs amongst the predicates. Together the Euthydemus and the Sophist show that sentences are neither names nor lists of names, and that naming is different from predication. And at least in the simplest cases, those discussed in the Sophist, predication requires differentiation between what does and what does not satisfy a predicate.

Compositionality requires that the meanings of complex expressions are determined by the simplest expressions occurring in them and the way they are assembled. But not only are sentences composed of simpler expressions, they are composed of expressions that serve different functions. ${ }^{17}$

\footnotetext{
${ }^{13}$ McCabe's translation, see 'First chop your logos ...' (4).

${ }^{14}$ An observation I owe to McCabe.

${ }^{15}$ For much of the dialogue it seems irrelevant whether Euthydemus or Dionysodorus speaks, or whether there are one or two sophists. In this episode, it is not. Euthydemus tells Dionysodorus off for letting Socrates destroy the argument by asking back. 'And Dionysodorus blushed.' (297a7-8, tr. Kent Sprague) We see them as persons when they get cross with Socrates and each other.

${ }^{16}$ McCabe's translation, see 'First chop your logos ...' (4).

${ }^{17}$ Ctesippus final exclamation when debate breaks down, 'Bravo, Heracles, what a fine argument!', elicits the oddest question of them all, 'And Dionysodorus said, Is Heracles a bravo, or is a bravo Heracles?' (303a6-8, tr. Kent Sprague). The different functions of expressions, that previously even the sophists respected to some degree, are finally overthrown.
} 
Sayings can fail not least because they come in opposites: true and false, assertion and denial, affirmation and negation. I aim at the truth, my aim fails and I speak falsely. I should have done the opposite: denied what I asserted, negated what I affirmed. There is no opposite of naming. There is no naming an opposite object. Objects do not have opposites. Predicates come in contradictory pairs, names don't. ${ }^{18}$

In the Sophist, Plato writes that 'since there is true and false speech, and [...] thinking appeared to be the soul's conversation with itself, belief the conclusion of thinking, and what we call appearing the blending of perception and belief, it follows that since these are all the same kind of thing as speech, some of them must sometimes be false.' (264a8-b4, tr. White) This sounds false at first: why shouldn't there be some lucky thinkers who never think falsehoods? Frege, however, observes that there must be false thoughts, because otherwise we cannot explain the meaning of negated sentences compositionally: $\neg p$ is true if and only if $p$ is false. (Frege, 1918b) We sometimes need to consider falsities, if only to reject them, as we would in a proof by contradiction, or, indeed, a Socratic dialogue.

Socrates' account of meaning shows 'that there is a great deal more to be said about the things that correspond to the words than is allowed by an "exact" sophistic account of language, truth and meaning.' (15) Naming may be momentary, but predication can be diachronic. To be able to speak truly about such process such as learning, the meanings of our words need to remain fixed while the process moves on. The concept expressed by or the sense of the predicate remains stable, while the process changes aspects and we continue to speak truly.

The third ingredient of chopped logos is the odd one out. If truth is essentially different from the relation between a name and its bearer, then, although the sophists may have some conception of the latter, they do not have a notion of truth. And so, due to the intimate connection between saying and truth, the sophists have no account of saying either. ${ }^{19}$

Conversely, if the sophists have no account of saying, then, by the close connection between saying and truth, they have no account of truth either. But truth is the link between language and reality. What the sophists say is cut off from reality.

The consequences of the sophistic theory of meaning are dire. The sophists 'are not self-refuters, but refuters of the self.' (28) The second half of this commentary gives another way of looking at this conclusion. Knowledge and belief are propositional attitudes. The sophists may have something to say about naming, but they have no account of truth and no account of the meanings of propositions, no account of what can take the place of $p$ in 'I know that $p$ ' and 'I believe that $p^{\prime}$. They can utter the words that their father is a dog and their mother a sea urchin, but, on the sophistic theory of meaning, far from everyone knowing everything, no one knows or even believes anything, as it is not an account of the kind of thing that can be known or believed. ${ }^{20}$

\footnotetext{
${ }^{18}$ Geach uses this observation to prove that no name is a predicate. (Geach, 1962, 31ff)

${ }^{19}$ If we accept Frege's context principle, the sophists do not even have a notion of naming: 'It is necessary to ask for the meaning of words in the context of a sentence, not in isolation.' (Frege, 1884, XXII)

${ }^{20}$ Aristotle makes a similar move with respect to the apparent deniers of the law of noncontradiction. 'The many writers on nature' may use contradictory language, but they cannot
} 
In this commentary I followed up some of McCabe's thoughts to draw attention to the relevance of Plato to contemporary investigations in the theory of meaning and philosophical logic. Those began with Frege. To my knowledge, Frege never refers to Plato. A strange omission from the man who wrote that 'if in the constant flux of things nothing firm, eternal, ever lasted, then the intelligibility of the world would cease and everything collapse into confusion.' (Frege, 1884, XIX) The problem of falsity is of crucial importance to Frege, too, for whom, as for Plato on McCabe's account, it is not something to be avoided down the line, but a starting point of logical investigations (see (Frege, 1918b)). The similarities between Plato and Frege are noticeable. And despite the differences, it seems to me that Frege and Plato grappled with very similar issues in the foundations of logic. I think McCabe will agree.

\section{References}

Anscombe, G. E. M. (1971). An Introduction to Wittgenstein's Tractatus. London: Hutchinson and Co.

Aristotle (1985). Metaphysics, translated by W. D. Ross, rev. J. Barnes. In J. Barnes (Ed.), The Complete Works of Aristotle. Princeton University Press.

Barcan Marcus, R. (1961). Modalities and intensional languages. Synthese 14(4), 303-322.

Davidson, D. (2001a). Introduction. In Inquiries into Truth and Interpretation. Oxford University Press.

Davidson, D. (2001b). True to the facts. In Inquiries into Truth and Interpretation. Oxford: Oxford University Press.

Denyer, N. (1991). Language, Thought and Falsehood in Ancient Greek Philosophy. London, New York: Routledge.

Dummett, M. (1978). Introduction. In Truth and other Enigmas. Cambridge, Mass.: Harvard University Press.

Dummett, M. (1981). Frege. Philosophy of Language (2 ed.). London: Duckworth.

Dummett, M. (1993a). Language and truth. In The Seas of Language. Oxford: Oxford University Press.

Dummett, M. (1993b). The Logical Basis of Metaphysics. Cambridge, Mass.: Harvard University Press.

Frege, G. (1884). Die Grundlagen der Arithmetik. Eine logisch-mathematische Untersuchung über den Begriff der Zahl. Breslau: H. \& M. Marcus.

Frege, G. (1893). Grundgesetze der Arithmetik. Begriffsschriftlich abgeleited. I. Band. Jena: Hermann Pohle.

Frege, G. (1918a). Der Gedanke. Eine logische Untersuchung. Beiträge zur Philosophie des deutschen Idealismus 1, 58-77.

believe what they say: 'it is impossible for a man to believe the same thing to be and not to be, as some think Heraclitus says; for what a man says he does not necessarily believe.' (Metaphysics $1005 b 23-26$, tr. Ross) Maybe for the Heracliteans of the Theaetetus the best we can achieve is a momentary naming, as an event pops up and disappears again in the constant flux. It is a common interpretation - triggered by images such as the divided line (Republic 509d6 ff) - that Plato agreed with Heraclitus in that there can be no knowledge, but only belief or opinion, about the physical world. McCabe's account suggests that either Plato did not think this or that he changed his mind. We must draw a stronger conclusion from the Euthydemus: there can be neither knowledge nor opinion about a Heraclitean world. See also (McCabe, MM, 2000, chapter 4). 
Frege, G. (1918b). Die Verneinung. Eine logische Untersuchung. Beiträge zur Philosophie des deutschen Idealismus 1, 143-157.

Geach, P. T. (1962). Reference and Generality. Ithaca, New York: Cornell University Press.

Kürbis, N. (2015). What is wrong with classical negation? Grazer Philosophische Studien 92(1), 51-85.

Marques, T. (2018). This is not an instance of (E). Synthese 195(3), 1035-1063.

McCabe, MM (2000). Plato and his Predecessors. The Dramatisation of Reason. Cambridge: Cambridge University Press.

Mill, J.S. (1882). A System of Logic (8 ed.). New York: Harper and Brothers.

Plato (1921). Sophist, translated by H. N. Fowler. Cambridge, MA, Harvard University Press; London, William Heinemann Ltd.

Plato (1997a). Euthydemus, translated by R. Kent Sprague. In J. M. Cooper, , and D. S. Hutchinson (Eds.), Plato. The Complete Works. Indianapolis: Hackett.

Plato (1997b). Republic, translated by G. M. A. Grube, rev. C. D. C. Reeve. In J. M. Cooper and D. S. Hutchinson (Eds.), Plato. The Complete Works. Indianapolis: Hackett.

Plato (1997c). Sophist, translated by N. P. White. In J. M. Cooper and D. S. Hutchinson (Eds.), Plato. The Complete Works. Indianapolis: Hackett.

Plato (1997d). Statesman, translated by C. J. Rowe. In J. M. Cooper and D. S. Hutchinson (Eds.), Plato. The Complete Works. Indianapolis: Hackett.

Plato (1997e). Theaetetus, translated by M.J. Levett, rev. by M. F. Burnyeat. In J. M. Cooper and D. S. Hutchinson (Eds.), Plato. The Complete Works. Indianapolis: Hackett.

Prior, A. N. (1967). Correspondence theory of truth. In P. Edwards (Ed.), The Encyclopedia of Philosophy, Volume 2, pp. 223-232. London: Macmillan.

Ramsey, F. P. (1978). Facts and propositions. In D. Mellor (Ed.), Foundations. Essays in Philosophy, Logic, Mathematics and Economics. London, Henley: Routledge and Kegan Paul.

Russell, B. (1905). On denoting. Mind 14(56), 479-493.

Russell, B. (1910). On the nature of truth and falsehood. In Philosophical Essays. Cambridge: Cambridge University Press.

Russell, B. (1918). The philosophy of logical atomism. The Monist 28(4), 495-527.

Russell, B. (2001). The Problems of Philosophy. Oxford: Oxford University Press.

Tarski, A. (1956). The concept of truth in formalised languages. In Logic, Semantics, Metamathematics. Oxford: Clarendon Press.

Weiss, B. (2007). Anti-realist truth and anti-realist meaning. American Philosophical Quarterly 44(3), 213-228.

Wittgenstein, L. (1953). Philosophische Untersuchungen. Frankfurt a. M.: Suhrkamp. 